\title{
Honey Value Chain Analysis in East Guji Zone, Southern Oromia Regional State, Ethiopia
}

\author{
Tesfu Nega ${ }^{1, *}$, Demto Mamo ${ }^{2}$ \\ ${ }^{1}$ Oromia Agricultural Research Institute, Finfinne, Ethiopia \\ ${ }^{2}$ Department of Agricultural Economics, Bore Agricultural Research Centre, Bore, Ethiopia
}

Email address:

tesfishnega10@gmail.com (T. Nega)

${ }^{*}$ Corresponding author

To cite this article:

Tesfu Nega, Demto Mamo. Honey Value Chain Analysis in East Guji Zone, Southern Oromia Regional State, Ethiopia. International Journal of Agricultural Economics. Vol. 6, No. 4, 2021, pp. 162-171. doi: 10.11648/j.ijae.20210604.13

Received: June 17, 2021; Accepted: July 19, 2021; Published: July 28, 2021

\begin{abstract}
The study was conducted in three districts of east Guji zone to analyze honey value chain. Guji zone has the external favorable environmental conditions that are in favor of honey production and marketing. However, current knowledge on honey product value chain is lacking. A total of 120 households were interviewed by using semi-structured questionnaire, key informant interview using checklists were primary data collection methods. The data were collected from 11 traders and 14 honey consumers by using interviewed. The collected data was analyzed by using SPSS. The major honey value chain actors in the study area was identified input suppliers, producers, local collectors, cooperatives, wholesalers, retailers, processors and final consumers of the product. The study result showed that honey producers was constrained by Pests and Predators, absconding, lack of Bee forage, agro-chemical application, lack of beekeeping equipments, lack of institutional linkage, marketing constraints and lack of modern input supply and traditional hives bought to high price from local market. While governmental and non-governmental- organizations are identified honey value chain supporters in the study areas. Four market channels were identified. From identified honey marketing channels (producers - collectors - cooperatives - processors consumer) are the major share of honey goes to marketing through channel II. The study suggests that beekeeping and districts agricultural development agents through provision of appropriate training and formation of beekeeper unions and cooperatives to address problems and strengthening linkage/interaction among honey value chain actors, and supportive institutions.
\end{abstract}

Keywords: Honey, Value Chain Map, Marketing Channels, Constraints, Opportunities

\section{Introduction}

Ethiopia is one of the countries in the continent, which has the largest honeybee populations and owns big potential of honey production. Owing to its varied ecological and climatic conditions, Ethiopia is home to some of the most diverse flora and fauna in Africa. Its forests and woodlands contain diverse plant species that provide surplus nectar and pollen to foraging bees $[8,14]$. Ethiopia has a longstanding beekeeping practices that has been an integral part of other agricultural activities, where more than one million households keep honeybees [1]. Beekeeping subsector is dominantly for small-scale farmers and is contributing significantly to the increment off-farm income and toward poverty reduction in rural areas [15]. The subsector is also provides an employment opportunity and income source for subsistence smallholder farmer's mainly the small land holders and landless [2]. Honey is used as a sweeting agent in different food product [16]. Honey is considered as cash crop and only about $10 \%$ of the honey produced in the country is consumed by the beekeeping households [13]. The remaining $90 \%$ is sold for income generation [9]. Traditional beekeeping belongs to the oldest agricultural activities in Ethiopia and still is a major integral component in today's agricultural economy of the country [7]. Beekeeping is a sustainable and high potential activity for local communities to gain additional income through non-timber forest products $[4,6]$. Beekeeping does not require much land or high starting costs, and people from child to advanced age are able to perform this activity without advanced skills $[5,10]$. Recently, the Ethiopian government is intensively working in 
organizing jobless urban and landless rural youth and women to involve in them in bee equipment production and beekeeping activities. A significant number of people are currently engaged in honey and beeswax collection, "tej" (honey wine) making, honey and beeswax processing and marketing [15]. Beeswax was also in the list of Ethiopian agricultural export commodities, though it was only in 2008 that the country got the EU accreditation to export its honey to EU market [3].

In Ethiopia, there are generally two honey harvesting seasons: the major one that lasts from October to November and the secondary one from April to June. However, in addition to these major harvesting periods, there are many small harvesting periods which depend on the type of flowering plants and rainfall patterns in different agroecologies [1], which experienced beekeepers and local people easily associate the harvesting season with the botanical origin of honey in their locality [11]. As Guji Zone we have identified that there is a potential of honey production (beekeeping) practices. But there is no work done so far concerning its value chain. Therefore this study is designed to fulfill the following objectives.

\subsection{Objectives}

The main objective of this study was to analyze honey value chains in East Guji Zone, Southern Oromia Regional State, Ethiopia.

\subsection{Specific Objectives}

1) Develop value chain maps and identify the major honey value chain actors in highland of Guji Zone.

2) To describe marketing costs and margins along the chain.

3) To identify the constraints and opportunities faced by honey value chain actors in the zone.

4) To identify strategic intervention areas for increasing the competitiveness of honey value chain in the zone.

\section{Methodology}

\subsection{Description of the Study Areas}

This study was undertaken in three major honey producing districts namely, Bore, Ana Sora and Dama districts found in Guji zone, Southern Oromia Regional State, Ethiopia. Description of each district is given below:-

Bore Districts: Astronomically, Bore district is located between $5^{\circ} 57^{\prime} 23^{\prime \prime}-6^{\circ} 26^{\prime} 52^{\prime \prime}$ northing latitudes and $38^{\circ} 25^{\prime} 51^{\prime \prime}$ $-38^{\circ} 56^{\prime} 21^{\prime \prime}$ easting longitudes. Bore district is situated in the Northwestern part of Guji Zone in the Oromia regional state.

The total area of Bore district is $500.440 \mathrm{~km}^{2}$ according to the GIS output of the District Statistics Department of DFEDD.

The following map shows the location of the district:

Geology: Bore district has the oldest rocks of PreCambrian strongly folded ancient basement rock. PreCambrian or basement complex rocks origin have been found in several parts of the district. According to Borena zone atlas of 1998 the major rocks available in the district are the upper proterozid and middle proterozid metamorphic rocks and lowers complex are Archie metamorphic rocks. The resultant land form such as trap series of basaltic followers are found in the district.

Climate: Bore district is characterized by two type of climatic zone, namely temperate. Dega (locally known as 'Bada') which starts in early April up to October and Woina dega (locally known as 'Bada dare') which starts late November up to reaches beginning of March). It is the most humid and sub humid moisture condition, which relatively longer growing season. The annual rain fall is about 900-1400 mm (recorded data 1996) and the annually temperature of the district range from $10.1^{\circ} \mathrm{C}$ up to $20.1^{\circ} \mathrm{C}$.

Soil Types: The major soils of Bore district are Nitosols (red basaltic soils) and Orthic Acrosols. The two soils are found on the highland areas, and they are red brown and black brown in colors and on sloping topography and their utilization are good under natural vegetation respectively. Anna Sora District: Astronomically, the district is located between $6^{\circ} 20^{\prime} 30^{\prime \prime}-5^{\circ} 57^{\prime} 30^{\prime \prime}$ northing latitudes and $38^{\circ} 39^{\prime} 30^{\prime \prime}$ - $38^{\circ} 57^{\prime} 30^{\prime \prime}$ easting longitudes. The district is situated in the Northern part of Guji Zone in the oromia regional state. The district share common boundaries with Bore district to the northern, southeast with the Adola Rede and SNNP Sidama Zone to the east, and Uraga district to the western direction.

Geology: The district has the oldest rocks of preCambrians strongly folded ancient basement rock. PreCambrian or basement complex rock original have been found in the several parts of the district.

Climate: The district is characterized by two type of climatic zone, namely temperate, Dega (locally known as Bada) which starts in early April up to October and Woina Dega (locally known as Bada-dare) which starts late November up to reaches the beginning of March). It is most humid and sub humid moisture condition, which has relatively longer growing season. The annual rainfall nearly about $122.7 \mathrm{~mm}$ and the annual temperature of the district is nearly about $10.1^{\circ} \mathrm{C}$ up to $20^{\circ} \mathrm{C}$.

Soil Types: The major soils of the district are Nitosols (red basaltic soils) and Orthic Acrosoils. These two soils are found on the highland areas of the district, and they are red brown and black brown in colors and on sloping topography and their agricultural utilization are good under natural vegetation cover, respectively.

Dama district is situated at a distance of $401 \mathrm{~km}$ from Finfinne/Addis Ababa and $235 \mathrm{~km}$ from the zonal capital city, Negelle town. The district has an area of $375.270 \mathrm{~km}^{2}$. It is an area where a mixed farming economic activity takes place, which is the major livelihood of the people. The Dama is classified into 18 peasants association and one urban center under study year.

The expansion of social services, secondary economic activities and modern means of transportation and communication are in their present stage of development.

In organizing this document, serious problems were faced, 
particularly in getting reliable and up-to-date data and information. The document incorporates basic information about the district. The document, being the first of its kind, gives a general hint about the district and accordingly could be used as a benchmark for further studying about the district.

\subsection{Sampling Procedure and Sample Size}

Multi-stage sampling procedure was using to select the sample farmers based on their potential of honey production. In the first stage, Bore, Ana Sora and Dama districts was selected purposively based on their honey production potential. In the second stage, with the consultation of districts livestock office kebeles in each district were stratified into honey producer and non producers; from these two groups honey producers' kebeles were selected. In the third stage, two kebeles were randomly selected from each district from the list of groups that produce honey. In the fourth stage, 20 honey producing households were selected randomly from the list of honey producers from the sampled kebeles. Finally, a total of 120 sample honey producers households were used for this study.

\subsection{Sources and Method of Data Collection}

Both primary and secondary data sources were used for this study. Primary data sources were used to collect through household survey, Key informant interview and Focus group discussions was held with farmers, development agents, district experts and traders. Secondary data sources were used to collect from districts livestock offices and also from all honey value chain actors. Different and relevant published and unpublished reports, websites were reviewed to generate relevant secondary data on beekeeping and honey value chain.

\subsection{Method of Data Analysis}

Descriptive statistics would be used to explain basic characteristics of the chain members and gross margin analysis to examine marketing costs and margin of different market participant. The data collected from each participant of the chain was immediately coded in accordance appropriate to feed into software (computer). After feeding the data in to the software (computer), validation and consistence check for the purpose of error checking was carried out before any analytical work. Appropriate statistical software such SPSS and STATA software was used to analyze the collected data.

\subsection{Data Analysis for Margin and Cost of Marketing}

When there are several participants in the market chain the margin is calculated by finding the price variations at different segments and then comparing them with final price to the consumer. The consumer price then is the base or common denominator for all marketing margins. Computing the Total Gross Marketing Margin (TGMM) is always related to the final price or the price paid by the end consumer and is expressed as a percentage [12]. The formula to calculate
TGMM is given as:

$$
\text { TGMM }=\frac{\text { Consumers price-Farmers' Price }}{\text { Consumer's price }} \times 100
$$

It is useful to introduce here the idea of producer participation farmer's portion or producer's gross margin (GMM) which is the portion of the price paid by the end consumer that belongs to the farmer as a producer. The producer's margin or share in the consumer price (GMMp) is calculated as:

$$
\text { GMMp }=\frac{\text { Consumer price }- \text { Marketing cost }}{\text { Consumer price }} \times 100
$$

The consumer price share/portion of market intermediate is calculated as:

$$
\mathrm{MM}=\frac{\text { Selling price }- \text { Buying price }}{\text { Final Consumer Price }} \times 100
$$

Where: $\mathrm{MM}=$ Marketing Margin (\%)

In marketing chain with only one trader between producer and consumer, the net marketing margin (NMM) is the percentage over the final price earned by the intermediary as his net income once his marketing costs are deducted. The percentage of net income that can be classified as pure profit (i. e., return on capital) depends on the extent to which factors such as the middleman's own, often imputed, salary are included in the calculation of marketing costs.

$$
\mathrm{NMM}=\frac{\text { Gross marketing margin }- \text { Marketing cost }}{\text { Consumers' price }} \times 100
$$

Where: NMM=Net Marketing Margin.

\section{Results and Discussions}

\subsection{Socio-Economic Characteristics of Sample Respondents}

Tables 1 and 2 present demographic and socioeconomic characteristics of the sample respondents. The total sample size of farm respondents handled during the survey was 120 .

\subsection{Sex of Respondents}

As shown in below table 1, out of total households head interviewed $85.83 \%$ were male headed households while $14.17 \%$ were female headed households.

\subsection{Education Level of Respondents}

The survey result shows that about $57.5 \%$ and 20.83 attended primary and secondary school education, respectively, however, $15.83 \%$ and $5.83 \%$ of the sampled household heads were illiterate and attended adult education, respectively. In both theoretical and practical situations, education level plays an immense role in ensuring household access to basic needs such as food, shelter and clothing. Skills and education increase the working efficiency resulting into more income and food security. Educational qualification has an effect in honey production. 


\subsection{Marital Status of Respondents}

The survey result shows that about marital status of sampled household heads were 99.17 percent of the beekeepers households are married while only 0.83 percent of respondents are divorced.

Table 1. Socio-economic characteristics of households (Categorical variables).

\begin{tabular}{|c|c|c|c|c|c|c|c|c|c|}
\hline \multirow{2}{*}{ Variable } & \multirow{2}{*}{ Items } & \multicolumn{2}{|c|}{ Bore $(\mathrm{N}=40)$} & \multicolumn{2}{|c|}{ Ana Sora $(N=40)$} & \multicolumn{2}{|c|}{ Dama $(N=40)$} & \multicolumn{2}{|c|}{ Total $(\mathbf{N}=120)$} \\
\hline & & $\mathbf{N}$ & $\%$ & $\mathbf{N}$ & $\%$ & $\mathbf{N}$ & $\%$ & $\mathbf{N}$ & $\%$ \\
\hline \multirow{2}{*}{ Sex } & Male & 28 & 70 & 36 & 90 & 39 & 97.5 & 103 & 85.83 \\
\hline & Female & 12 & 30 & 4 & 10 & 1 & 2.5 & 17 & 14.17 \\
\hline \multirow{4}{*}{ Education } & Illiterate & 10 & 25 & 5 & 12.5 & 4 & 10 & 19 & 15.83 \\
\hline & Adult education & 3 & 7.5 & 2 & 5 & 2 & 5 & 7 & 5.83 \\
\hline & Primary & 20 & 50 & 26 & 65 & 23 & 57.5 & 69 & 57.5 \\
\hline & Secondary & 7 & 17.5 & 7 & 17.5 & 11 & 27.5 & 25 & 20.83 \\
\hline \multirow{4}{*}{$\begin{array}{l}\text { Marital } \\
\text { status }\end{array}$} & Single & - & - & - & - & - & - & - & - \\
\hline & Married & 39 & 97.5 & 40 & 100 & 40 & 100 & 119 & 99.17 \\
\hline & Divorced & 1 & 2.5 & - & - & - & - & 1 & 0.83 \\
\hline & Widowed/er & - & - & - & - & - & - & - & - \\
\hline
\end{tabular}

Source: Own computation from survey result, 2019.

\subsection{Family Size of the Household Respondents}

The average family size of the total sample respondents was found to be 4.97, 5.79 and 6.59 persons in Bore, Ana Sora and Dama districts, respectively.

\subsection{Farming Experience of Household Respondents}

The average years of farming experience related to honey production was $13.67,16.12$ and 16.85 years of farming experience in honey production Bore, Ana Sora and Dama districts, respectively.

\subsection{Farming Size of Household Respondents}

One of the most important factors that influence crop production is resource endowment, availability of land for crop production. Land is the basic asset of the sample farmers. The survey result with respect to land holding of the respondents reveals that an average size of land holding per household is 3.52 ha, 4.63 ha and 4.23 ha Bore, Ana Sora and Dama districts, respectively.

Table 2. Demographic and socio-economic characteristics of samples (Continuous variables).

\begin{tabular}{|c|c|c|c|c|c|c|c|c|}
\hline \multirow{2}{*}{ Variables } & \multicolumn{2}{|c|}{ Bore $(\mathrm{N}=40)$} & \multicolumn{2}{|c|}{ Ana Sora $(N=40)$} & \multicolumn{2}{|c|}{ Dama $(N=40)$} & \multicolumn{2}{|c|}{ Total $(\mathrm{N}=120)$} \\
\hline & Mean & SD & Mean & SD & Mean & SD & Mean & SD \\
\hline Age & 36.65 & 1.67 & 39.9 & 1.96 & 43.65 & 2.03 & 40.07 & 1.11 \\
\hline Family size & 4.97 & 0.49 & 5.79 & 0.81 & 6.59 & 0.83 & 5.79 & 0.42 \\
\hline Farm Experience & 13.67 & 1.36 & 16.12 & 1.56 & 16.85 & 1.4 & 15.55 & 0.83 \\
\hline Farm size (ha) & 3.52 & 0.38 & 4.63 & 0.41 & 4.23 & 0.4 & 4.12 & 0.23 \\
\hline
\end{tabular}

Source: Own computation from survey result, 2019.

\subsection{Honey Production in the Study Areas}

During the survey, the average yield of crude honey production obtained from traditional hives and locally prepared transitional hives in the districts were $20.81 \mathrm{~kg} / \mathrm{hive}$ and $18.67 \mathrm{~kg} / \mathrm{hive}$, respectively (below table 3 ).

Table 3. Average yield of crude honey production in $\mathrm{kg} / \mathrm{hives}$.

\begin{tabular}{|c|c|c|c|c|}
\hline Variable & Mean & SD & Min & Max \\
\hline Average yield from traditional hives & 20.81 & 16.707 & 4 & 30 \\
\hline Average yield from transitional hives & 18.67 & 2.309 & 16 & 20 \\
\hline
\end{tabular}

Source: own survey result, 2019.

\subsection{Numbers of Beehives Owned Household Heads}

From the table 4, on average 24.57 of households were used traditional hives while 3.5 and 2.5 were used transitional and modern hive respectively. This showed that majority of the households were engaged in traditional beekeeping practice in the study areas. This also indicated that there is a shortage of modern hive in the study areas. Refer to the below result comparing to the three selected districts (Bore, Ana Sora and Dama) the average number of traditional hives owned per household was higher in Ana Sora district. Bore district was the second and Dama district was the third which is 39.82 , 17.65 and 16.25 respectively. 
Table 4. Average numbers of beehives per sample households.

\begin{tabular}{lllllllll}
\hline \multirow{2}{*}{ Beehives } & \multicolumn{1}{c}{ Bore $(\mathbf{N}=\mathbf{4 0})$} & \multicolumn{2}{c}{ Ana Sora $(\mathbf{N}=\mathbf{4 0})$} & \multicolumn{2}{c}{ Dama $(\mathbf{N}=\mathbf{4 0})$} & \multicolumn{2}{c}{ Total $(\mathbf{N}=\mathbf{1 2 0})$} \\
\cline { 2 - 9 } & Mean & SD & Mean & SD & Mean & SD & Mean & SD \\
\hline Traditional hives & 17.65 & 2.34 & 39.82 & 12.09 & 16.25 & 1.41 & 24.57 & 4.21 \\
Transitional hives & 2 & - & 3.4 & 0.87 & 7 & - & 3.5 & 0.75 \\
\hline
\end{tabular}

Source: Own survey result, 2019.

\subsection{Months of Peak Honey Harvested Sample Respondents}

Honey is harvested in the study areas from March through April and from April to May (peak harvested periods) every year. Considering the months of honey harvested sample respondents, $95 \%$ of sample respondents honey harvested in April, 2.5\% of sample respondents honey harvested in March and $2.5 \%$ of sample respondents honey harvested in May. This result showing that majority of the households is honey harvested in April.

Table 5. Months of peak honey harvested sampled respondents.

\begin{tabular}{|c|c|c|c|c|c|c|c|c|}
\hline \multirow{2}{*}{ Months of harvested } & \multicolumn{2}{|c|}{ Bore $(\mathrm{N}=40)$} & \multicolumn{2}{|c|}{ Ana Sora $(N=40)$} & \multicolumn{2}{|c|}{$\operatorname{Dama}(N=40)$} & \multicolumn{2}{|c|}{ Total $(\mathrm{N}=120)$} \\
\hline & $\mathbf{N}$ & $\%$ & $\mathbf{N}$ & $\%$ & $\mathbf{N}$ & $\%$ & $\mathbf{N}$ & $\%$ \\
\hline April & 40 & 100 & 35 & 87.5 & 39 & 97.5 & 114 & 95 \\
\hline March & - & - & 2 & 5 & 1 & 2.5 & 3 & 2.5 \\
\hline May & - & - & 3 & 7.5 & - & - & 3 & 2.5 \\
\hline
\end{tabular}

Source: Own survey result, 2019.

\section{Honey Value Addition Activities}

From below (Table 6) data the households honey value addition activity $53.33 \%$ of respondents respond that grading,
$24.17 \%$ of respondents replied that packing, $14.17 \%$ of respondents respond that others, $5.83 \%$ of respondents replied that labeling and $2.5 \%$ of respondents reacted that separation of honey from wax.

Table 6. Households across honey value addition.

\begin{tabular}{lllll}
\hline Value addition activity & N=120 & \% & Cum \\
\hline Grading & 64 & 53.33 & 53.33 \\
Packing & 29 & 24.17 & 77.5 \\
Labelling & 7 & 5.83 & 83.33 \\
Separation of honey from wax & 3 & 2.5 & 85.83 \\
Others & 17 & 14.17 & 100 \\
\hline
\end{tabular}

Source: Own survey result, 2019.

\subsection{Access to Institutional Service of Farm Households}

In the Table 7, depicts that out of the total respondents of honey producing sample households, about $51.67 \%$ of the farmers reported that they had access to extension service in 2019 production season. About $48.33 \%$ of the farmers reported that they had no access to extension service. The extension services providers were office of agriculture experts, DAs and innovative farmers.

\subsection{Access to Credit Service}

Only $15 \%$ of sampled producers had access to credit in the study areas.

\subsection{Access of Market Information}

Table 6 , about $70 \%$ of sampled farmers had access to market information from different sources and only $30 \%$ had no access to market information.

\subsection{Labour Shortage}

From sampled households about $54.17 \%$ were labour shortage for beekeeping activities and $45.83 \%$ were not participating on off/non-farm income activities (Table 7).

\subsection{Off/Non-farm Income Activities}

From sampled households about 35\% were participating on off/non-farm income activities and $65 \%$ were not participating on off/non-farm income activities (Table 7).

\subsection{Input Supplier}

From below (Table 8), showing that the input supplier for beekeeping activities $59.17 \%$ of respondents respond that made by individual, $26.67 \%$ of respondents replied that district agricultural and natural resource offices and $14.17 \%$ 
of respondents respond that bought from market. This result indicated that there is a shortage of input supplier for

beekeeping activities.

Table 7. Access to service of sample households.

\begin{tabular}{|c|c|c|c|c|c|c|c|c|c|}
\hline \multirow{2}{*}{ Variables } & & \multicolumn{2}{|c|}{ Bore $(N=40)$} & \multicolumn{2}{|c|}{ Ana Sora $(\mathrm{N}=40)$} & \multicolumn{2}{|c|}{ Dama $(\mathrm{N}=40)$} & \multicolumn{2}{|c|}{ Total $(\mathrm{N}=120)$} \\
\hline & & $\mathbf{N}$ & $\%$ & $\mathbf{N}$ & $\%$ & $\mathbf{N}$ & $\%$ & $\mathbf{N}$ & $\%$ \\
\hline \multirow{2}{*}{ Extension Contact } & Yes & 24 & 60 & 21 & 52.5 & 17 & 42.5 & 62 & 51.67 \\
\hline & No & 16 & 40 & 19 & 47.5 & 23 & 57.5 & 58 & 48.33 \\
\hline \multirow{2}{*}{ Access credit } & Yes & 2 & 5 & 2 & 5 & 14 & 35 & 18 & 15 \\
\hline & No & 38 & 95 & 38 & 95 & 26 & 65 & 102 & 85 \\
\hline \multirow{2}{*}{ Market information } & Yes & 21 & 25 & 37 & 44.05 & 26 & 30.95 & 84 & 70 \\
\hline & No & 19 & 52.8 & 3 & 8.33 & 14 & 38.89 & 36 & 30 \\
\hline \multirow{2}{*}{ Labour shortage } & Yes & 22 & 33.8 & 25 & 38.46 & 18 & 27.69 & 65 & 54.17 \\
\hline & No & 18 & 32.7 & 15 & 27.27 & 22 & 40 & 55 & 45.83 \\
\hline \multirow{2}{*}{ Off/Non-farm income } & Yes & 12 & 28.5 & 21 & 50 & 9 & 21.43 & 42 & 35 \\
\hline & No & 28 & 36.3 & 19 & 24.38 & 31 & 40.26 & 78 & 65 \\
\hline
\end{tabular}

Source: own survey result, 2019.

Table 8. Input supplier for beekeeping activities.

\begin{tabular}{llll}
\hline+ & N & \% & Cum \\
\hline District agricultural and natural resource offices & 32 & 26.67 & 26.7 \\
Bought from market & 17 & 14.17 & 40 \\
\hline
\end{tabular}

Source: Own survey result, 2019

\subsection{Constraints and Opportunities of Honey Value Chain}

\subsubsection{Major Constraints}

Constraints identification and solution searching is important to utilize the beekeeping sub-sector more efficiently and effectively. During the survey, the respondents identified many challenges in honey production and marketing. As a result, prioritization of the problems was made to identify the most imperative constraints that hinder the development of beekeeping sub-sector in the study areas.

Table 9. The major constraints of honey production and marketing in the study areas.

\begin{tabular}{|c|c|c|c|c|c|c|c|c|c|}
\hline \multirow{2}{*}{ Constraints } & \multicolumn{2}{|c|}{ Bore $(\mathrm{N}=40)$} & \multicolumn{2}{|c|}{ Ana Sora $(\mathrm{N}=40)$} & \multicolumn{2}{|c|}{$\operatorname{Dama}(N=40)$} & \multicolumn{2}{|c|}{ Total $(\mathrm{N}=120)$} & \multirow{2}{*}{$\operatorname{Rank}$} \\
\hline & $\mathbf{N}$ & $\%$ & $\mathbf{N}$ & $\%$ & $\mathbf{N}$ & $\%$ & $\mathbf{N}$ & $\%$ & \\
\hline Pests and Predators & 20 & 50 & 10 & 25 & 19 & 22.5 & 49 & 40.83 & 1 \\
\hline Absconding & 17 & 42.5 & 11 & 27.5 & 16 & 40 & 44 & 36.67 & 2 \\
\hline Lack of Bee forage & 3 & 7.5 & 11 & 27.5 & 4 & 10 & 18 & 15 & 3 \\
\hline Agro-chemical application & - & - & 4 & 10 & 1 & 2.5 & 5 & 4.16 & 4 \\
\hline Lack of beekeeping equipments & - & - & 2 & 5 & - & - & 2 & 1.67 & 5 \\
\hline Lack of institutional linkage & - & - & 1 & 2.5 & - & - & & 0.83 & 6 \\
\hline \multicolumn{10}{|l|}{ Marketing constraints } \\
\hline Price variation & 27 & 67.5 & 35 & 87.5 & 24 & 60 & & 76.67 & 1 \\
\hline Lack of fair market & 11 & 27.5 & 3 & 7.5 & 16 & 40 & & 25 & 2 \\
\hline Lack of demand & 2 & 5 & 2 & 5 & - & - & & 3.33 & 3 \\
\hline
\end{tabular}

Source, own survey result, 2019

Regarding to above Table 9, the major constraints of beekeeping sample households in the study area, the survey result showing that the first highest constraints $40.12 \%$ of damage the honey is Pests and Predators, 36.67\% second constraints absconding, $15 \%$ the third constraints is lack of bee Forages and $4.16 \%$ constraints is agro-chemical application are pesticides and herbicides application and $1.67 \%$ lack of beekeeping equipments and the last one is lack of institutional linkage and diseases $0.83 \%$, respectively. The major marketing constraints in the study area, the first marketing constraints is price variation $76.67 \%$, the second marketing constraints is lack of fair market $25 \%$, and lack of demand to honey $3.33 \%$.

\subsubsection{The Major Opportunities}

Apiculture is one of the important agricultural sectors that enables to utilize natural resources that otherwise would be wasted, and contributes to national food products through pollination (Melaku et al., 2008). According to Bore, Ana Sora and Dama districts Agriculture and natural resource offices report, there is still huge potential to increase honey production and to improve the livelihood of the beekeepers in the study areas. Based on the survey conducted on the status of the Bore, Ana Sora and Dama districts beekeeping sub sector, it was inspected that it has lots of opportunities and constraints.

The opportunities of the districts honey sub-sector refer to the external favorable environmental conditions that are 
in favor of honey production and marketing. Some of these include availability and diversity of bee forage, availability of water, availability of strong colonies, availability of marketing access and demand of honey marketed. Moreover, the existing natural resource base, government has recently put in its agenda the need to develop apiculture as one of the strategies to reduce poverty and to diversify national exports.

This will be providing Bore, Ana Sora and Dama districts farmers the opportunity to access improved beekeeping technologies and capacity building (training on apiculture). Availability of market demand throughout the year, growing number of buyers, high experience in honey production and trade, marketing situation of bee products are some of the opportunities for honey production and marketing by most of the producers.

\subsection{Honey Value Chain Actors and Their Roles}

This study was identified different actors involved in the value chain of honey in the study area from early production up to the final consumption level within the zones. The major actors involved in honey value chain in the study area are input suppliers, producers, cooperatives, rural collectors, wholesalers, retailers, processors and final consumers of the product.

Input Suppliers: These are the first actors in honey value chain in the study areas. In the study area there are districts agricultural and natural resource offices input supplied for beekeeping activities and household bought from local market and other beekeepers.

Producers: These are the second actors in value chain of honey and the basis of market participant in honey markets. Traditionally, beekeepers work as integrated actor and perform two or more functions of value chain. They make their hives out of available local materials, catch and hive swarms, manage bees, harvest and process honey, packing and sell to the consumers. In the study area traditional hives for honey production are produced by the farmers (beekeepers) themselves and its price is $150 \mathrm{Birr} / \mathrm{hive}$ for those who buy it. They sell crude honey to rural collectors, retailers, wholesalers, cooperatives, processors and transit consumers at the local and district market center.

Rural honey collectors: are those actors who buy crude honey directly from smallholder producers at the local or village market in the districts. They are engaged in buying of honey from farmers and sell it to traders, retailers, cooperatives and consumers who come from different areas. Collectors play important roles of bulking, grading and sending the products to the various market outlets.

Collectors in the study area there are haven't license for honey collected.

Wholesalers: are those actors who receive honey directly from cooperatives and local market directly from farmers. Wholesalers have intimate relation with their customers or cooperatives that bring a bulk of honey for them.

Cooperatives: these are known for purchase of bulky products with better financial and information capacity in the study areas. Cooperatives bought crude honey directly from producers to their respect unions which process and pack honey for export market by extracting liquid honey from the honey comb and to local breweries. In addition, cooperatives process and pack honey by themselves and sell to wholesalers and local consumers at their own retailing shop.

Retailers: are small shops that engaged in honey trading in the districts and that delivered honey to end users. The retailers comprise some of the integrated suppliers who sell honey to local consumers. These include supermarkets, small shops in rural villages and urban centers. Collectors and wholesalers do also act as retailers since they sell small quantities of honey directly to consumers. In the study area honey retailers are very high.

Processors: These are actors who purchase crude honey from beekeepers and collectors then supply processed honey to global consumers by packing and sell to local consumers in the form of brewery locally known as tej and birzi. Honey processors in Guji Zone well- known Mea Boku Union honey process and packing to export market by extracting liquid honey from the honeycomb to sell for the global consumers.

Consumers: The honey produced in the study area passes through different chain actors to reach on the hand of final consumers. From the consumers' point of view the shorter the marketing chain, the more likely is the retail price going to be affordable. Consumers for this particular study mean those households who bought and consume honey. They are individual households they bought the commodity for their own consumption and other friends.

\subsection{Honey Value Chain Supporters}

The main honey value chain supporters who facilitate performance of the major value chain actors in the study area are:

Districts Livestock Office: They provide support for smallholder beekeepers in the study area on honey production and marketing. They give advice to honey bee colony management, processing, handling and storage, bee forage development and marketing information and linkage and give general training to improve the quality and quantity of honey produced in the districts.

Research Institutions: Provide technical support, like training and capacity building for beekeepers, cooperatives and for development on different aspects of beekeeping.

Micro Finance Institutions: It supports the sector through providing credit services for beekeepers and traders as credit supply is one of the major supporting activities of honey value chain.

Mapping Value Chain Actors, Supporters and Their Functions.

Mapping of value chain functions is considered to show the relationships and integrations of the processes and activities performed along the value chain. Major functions include input supply, production, trading, processing and consumption. Figure 1 displays these are interconnected with main channels in which honey flows to reach the consumers are mapped below: 

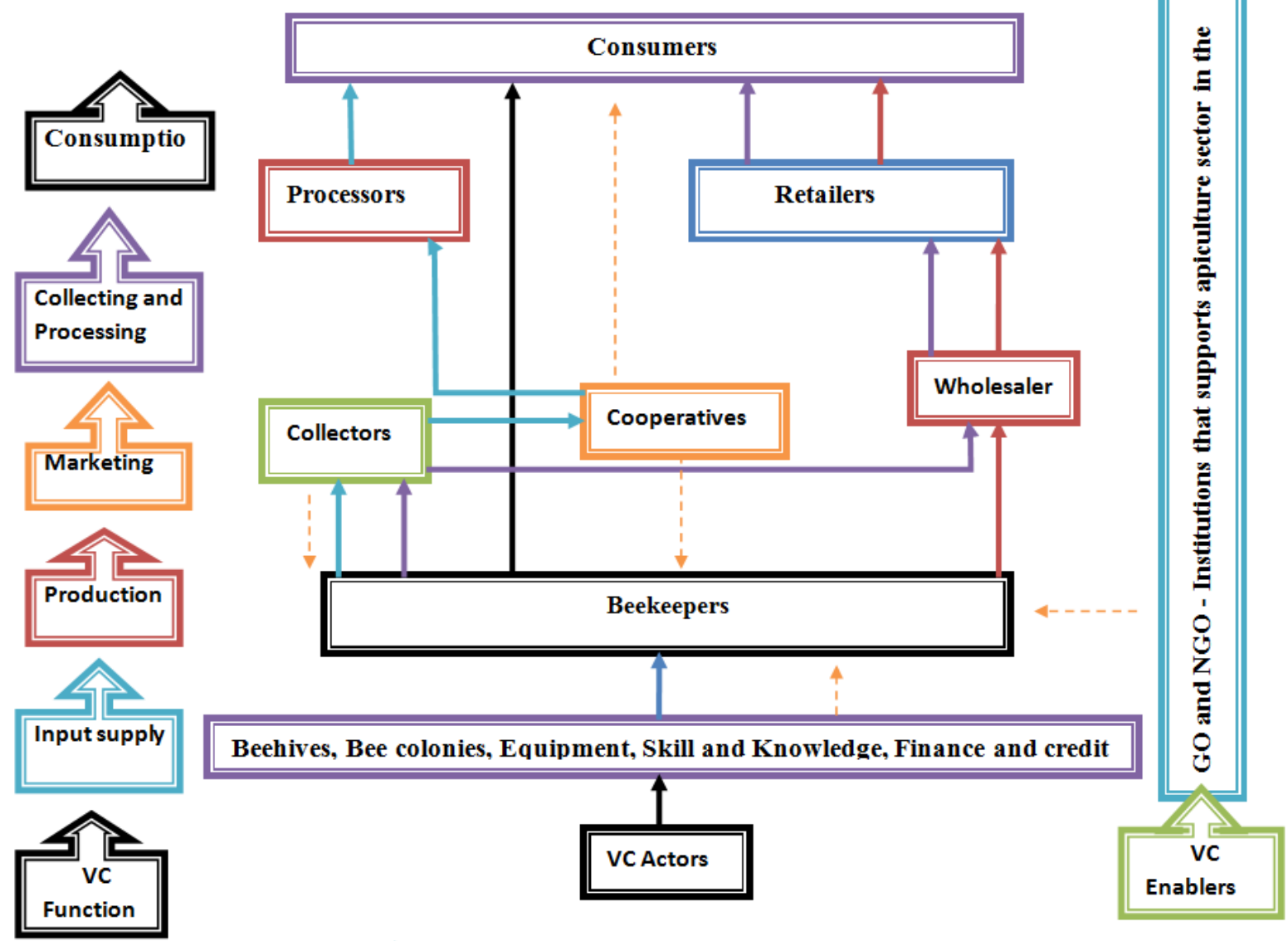

Note: $\longrightarrow$ Strong product flow

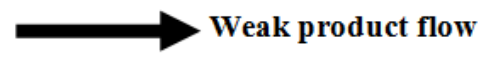

$-n_{--\ldots-c}$ Information flow

Source: Own sketch from survey result, 2019.

Figure 1. Honey Value Chain Map in the study areas.

Table 10. Marketing costs and benefit shares of actors in honey value chain.

\begin{tabular}{|c|c|c|c|c|c|c|}
\hline Item (Birr/Kg) & Producers & Collectors & Wholesalers & Cooperatives & Retailers & Sum \\
\hline Purchase prices & & 110 & 120 & 150 & 180 & 560 \\
\hline Production cost & 20.94 & & & & & 20.94 \\
\hline \multicolumn{7}{|l|}{ Marketing cost } \\
\hline Labor cost & & & & 8.42 & 9.52 & 17.94 \\
\hline Transport cost & & 8.33 & 5 & 16.85 & 3.57 & 33.75 \\
\hline Sorting cost & & & 8.33 & & 1.19 & 9.52 \\
\hline Packing cost & & 10 & 2 & 11.23 & 9.52 & 23.23 \\
\hline Load/unload cost & & 6.67 & 3.33 & 5.6 & 3.33 & 18.93 \\
\hline Processing cost & & & & 11.23 & 0.47 & 11.7 \\
\hline Others cost & & 4.16 & & 1.68 & 0.83 & 6.67 \\
\hline Total marketing cost & 15.65 & 29.16 & 18.66 & 55.01 & 28.43 & 146.91 \\
\hline Total cost & 36.59 & 29.16 & 18.66 & 55.01 & 28.43 & 167.85 \\
\hline Sale Price & 95 & 120 & 140 & 180 & 200 & 735 \\
\hline Market margin & 74.06 & 39.16 & 38.66 & 85.01 & 48.43 & 285.32 \\
\hline$\%$ share of margin & 26 & 13.7 & 13.5 & 29.8 & 17 & 100 \\
\hline
\end{tabular}

Source: Own computation from survey result, 2019.

\subsection{Honey Marketing Channels}

From the total produced honey in 2018/2019, $24127 \mathrm{~kg}$ of honey was supplied by sample respondents in Bore, Ana Sora and Dama districts to honey markets from the total quantity marketed. The main honey marketing channels identified from the point of production until the product reaches to the final consumer were: 
Channel I: Producer $\rightarrow$ Collector $\rightarrow$ Wholesaler $\rightarrow$ Retailer $\rightarrow$ Consumer: This channel represented $14.97 \%$ of total honey marketed during the survey period. The channel was found to be the second important marketing channel in volume $(3612 \mathrm{~kg})$.

Channel II: Producers $\rightarrow$ Collectors $\rightarrow$ Cooperatives $\rightarrow$ Processors $\rightarrow$ Consumers: This channel represented $73.77 \%$ of total honey marketed during the survey period. The channel was found to be the first important marketing channel in terms of volume (17800 kg).

Channel III: Producers $\rightarrow$ Wholesalers $\rightarrow$ Retailers

$\rightarrow$ Consumer: This channel represented $5.84 \%$ of total honey marketed during the survey period $(1410 \mathrm{~kg})$.

Channel IV: Producers $\longrightarrow$ Consumers: This channel represented $5.40 \%$ of total honey marketed during the survey period $(1305 \mathrm{~kg})$.

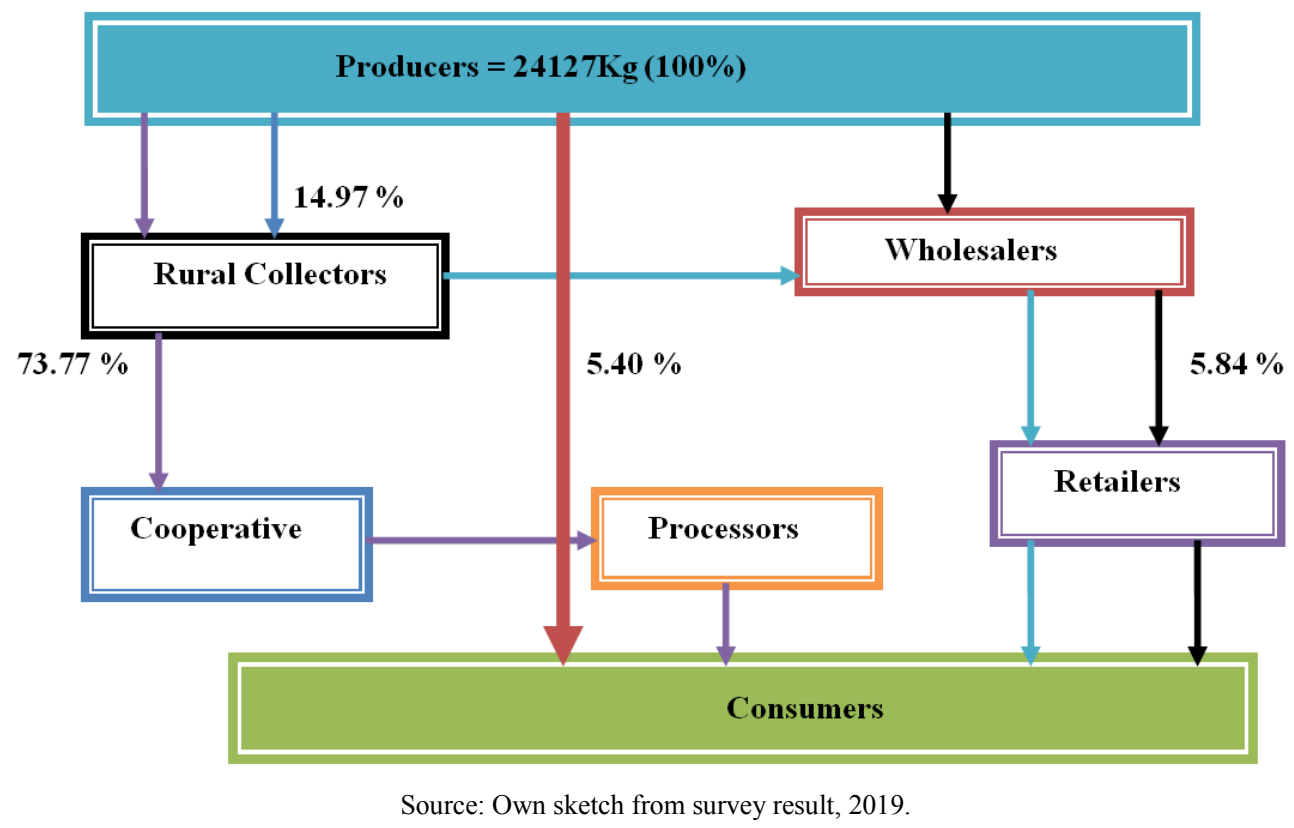

Figure 2. Honey marketing channel at different market actors in the study areas.

As indicated in Table 9, the survey results showed that the maximum producers share margin is highest to $29.8 \%, 17 \%$, cooperatives and retailers, respectively. The lowest producers share margin was taken by wholesalerse ${ }^{\text {ee }}$ and rural collectors in $13.5 \%$ and $13.7 \%$, respectively.

\section{Conclusion and Recommendations}

\subsection{Conclusions}

The study was aimed to analyze honey value chain in Guji zone, Bore, Ana Sora and Dama districts are huge potential for honey production due to favorable environmental condition and availability of bee forage and water. Honey had been identified in the study areas as a major cash income generating commodity. Honey production is the most important market oriented commodity in the study areas.

The data were generated by individual interview using pretested questionnaires.

A total of 120 household heads interviewed $85.83 \%$ were male headed while $14.17 \%$ were female headed households. About education level $57.5 \%$ of households attended primary and $20.83 \%$ of households attended secondary education while $5.83 \%$ of the households had adult education and $15.83 \%$ of households non-educated.

The average size of honeybee colony holding per household in the study areas were 24.57 traditional and 3.5 transitional.

The average years of beekeeping experience acquired for the entire sample was about 15.55 years. About 51.67 percent of respondents had access of extension contact with different frequencies. The remaining percentage $(48.33 \%)$ of respondents reported no extension contact.

Honey producers was constrained by Pests and Predators, absconding, lack of Bee forage, agro-chemical application, lack of beekeeping equipments, lack of institutional linkage, marketing constraints and lack of modern input supply and traditional hives bought to high price from local market.

The survey result indicated that there were no observed operational brokers in the honey marketing channel during the survey period. The honey collector's were found to purchase honey either directly from farmers at the local/districts market.

\subsection{Recommendations}

Possible recommendations that could be given on the basis of the study so as to be considered in the future intervention strategies which are aimed at the promotion of honey production and marketing of the study areas were as follows:

Train producers on appropriate beekeeping management practice. 
Create linkage between credit institution and farmers.

Demonstrating improved beehives, increasing the productiveness of bee colonies by improving bee forage.

Strengthening existing beekeepers cooperative to facilitate collection, processing and marketing of honey products.

The overall, efforts should be geared to develop efficient input delivery systems, knowledge-based production) to improve production side and introduction of value adding management practices and market linkage from marketing side are the most important aspect of enhancing the livelihood and source of producers.

Therefore, government actions are required to license and inspect computing honey product traders to ensure achievements of minimum cleanliness and quality standards in order to facilitate the honey production and marketing process.

\section{References}

[1] Adgaba N (2007). Atlas of pollen grains of major honeybee flora of Ethiopia, Holetta bee research centre, Holetta, Ethiopia.

[2] Ajabush D. (2018). Review of Economic and Ecological Importance of Bee and Bee Products in Ethiopia. Journal of Animal Husbandry and Dairy Science. 2 (2): 18-26.

[3] Assefa A. June 2009, "Market Chain Analysis of Honey Production: In Atsbi Wemberta District, Eastern Zone of Tigray National Regional State", M. Sc. Thesis.

[4] Bareke T, Addi A, Wakjira K (2018) Role and economic benefits of honey bees' pollination on fruit yield of wild apple (Malus sylvestris (L.) Mill.) in central highlands of Ethiopia. $\begin{array}{lllll}\text { Bee } & \text { World } 95 & \text { (4): } 113-\end{array}$ https://doi.org/10.1080/0005772X.2018.1522834

[5] Bradbear N (2009) Bees and their role in forest livelihoods: a guide to the services provided by bees and the sustainable harvesting, processing and marketing of their products. Nonwood Forest Products 19, Food and Agriculture Organization of the United Nations, Rome, Italy.
[6] Fikadu Z (2019). The contribution of managed honey bees to crop pollination, food security, and economic stability: case of Ethiopia. Open Agric J 13 (1): 175-181. https://doi.org/10.2174/1874331501913010175

[7] Fikru S (2015) Review of honey bee and honey production in Ethiopia. J Anim Sci 5 (10): 1413-1421.

[8] Girma Deffar, 1998. Non-Wood Forest Products in Ethiopia. EC-FAO Partnership Programme (1998-2000). Addis Ababa. pp. $1-5$.

[9] Hartmann I. (2004). - No Tree, No Bee - No Honey, No Moneyl: The Management of Resources and Marginalization in Beekeeping Societies of South West Ethiopia.

[10] ICIPE (2013) Linking insects to forest conservation through honey and silk. Department for International Development (DFID), Nairobi, Kenya. Accessible online (21.04.2021): https://assets.publishing.service.gov.uk/government/uploads/s ystem/uploads/attachment_data/file/228477/ICIPE__Linking_insects_to_forest_conservation_Feb13.p̄pdf.

[11] Legesse G (2013). Identification and characterization of major mono-floral honeys in Ethiopia. pp. 121-128.

[12] Mendoza, G., 1995. A Primer on marketing channels and margins. Lyme Rimer Publishers Inc., USA. 425 p.

[13] MoARD (2003). Honey and Beeswax marketing and development. In development, M. O. A. A. R. (Ed.) Plan 2003. Addis Ababa, Ethiopia.

[14] MoARD, 2006. Annual reports series 2005, 2006, Addis Ababa, Ethiopia.

[15] MoARD, 2007. Ministry of Agriculture and Rural Development Annual Reports Addis Ababa Ethiopia.

[16] Naik, A. P., Deshmukh, G. D., Londhe, G. K. and Thorat, D. D. (2017). Preparation of khoa burfi using honey as a sweetening agent. Asian Journal of Dairy and Food Research. 36 (3): 191-194. 